\title{
JNPH
}

Volume 7 No. 1 (April 2019)

(C) The Author(s) 2019

\section{KOMBINASI LIMBAH BATU BARA DAN LIMBAH CANGKANG KOPI SEBAGAI ADSORBEN DALAM MENURUNKAN KADAR BESI (Fe) PADA AIR SUMUR GALI}

\author{
COMBINATION OF COAL WASTE AND SHELL COFFE WASTE AS ADSORBEN IN \\ REDUCING IRON LEVELS (Fe) IN DUG WELLS WATER
}

\author{
RIANG ADEKO, DEFI ERMAYENDRI \\ POLITEKNIK KESEHATAN KEMENTERIAN KESEHATAN BENGKULU, JURUSAN \\ KESEHATAN LINGKUNGAN, JALAN INDRAGIRI NOMOR 3 \\ PADANG HARAPAN BENGKULU \\ Email: keslingpoltek@gmail.com
}

\begin{abstract}
ABSTRAK
Air merupakan kebutuhan dasar bagi kehidupan, khususnya bagi manusia yang selama hidupnya selalu memerlukan air. Air digunakan oleh manusia untuk keperluan sehari-hari seperti minum, mandi, cuci, kakus, dan sebagainya. Survey awal yang dilakukan pada tanggal 08 Februari 2018 di sumur gali warga RT. 04 RW. 03 Kelurahan Rawa Makmur Permai Kota Bengkulu setelah dilakukan pengukuran diperoleh Besi (Fe) 1,39 mg/L. Dari hasil pengukuran pada survey awal diketahui bahwa air sumur gali warga RT.04 RW.03 Kelurahan Rawa Makmur Permai Kota Bengkulu masih melebihi ambang batas yang dipersyaratkan oleh Permenkes RI No.32 Tahun 2017. Tujuan penelitian ini adalah untuk mengetahui penurunan kadar Fe sebelum dan sesudah perlakuan dengan menggunakan variasi ketebalan kombinasi batubara dan cangkang kopi $20 \mathrm{~cm}, 30 \mathrm{~cm}$, dan $50 \mathrm{~cm}$ serta untuk mengetahui variasi ketebalan paling efektif untuk menurunkan kadar Fe. Jenis penelitian ini menggunakan metode semi eksperimen (Quasi Experimental) dengan desain post test with control group, yaitu penelitian dilakukan sebelum dan sesudah perlakuan. Kemudian dicari perbedaan antara pengukuran dari keduanya dan perbedaan ini dianggap sebagai akibat perlakuan. Hasil penelitian diperoleh variasi ketebalan paling efektif untuk menurunkan kadar $\mathrm{Fe}$ adalah dengan ketebalan $50 \mathrm{~cm}$ yang dapat menurunkan kadar besi (Fe) hingga 51,79\%.
\end{abstract}

\section{Kata Kunci: Adsorben, Limbah Batu Bara, Limbah Cangkang Kopi, Kadar Besi, Sumur Gali}

\begin{abstract}
Water is a basic need for life, especially for humans who have always needed water. Water is used by humans for daily needs such as drinking, bathing, washing, latrines, and so on. A preliminary survey conducted on February 8, 2018 at the well dug RT residents. 04 RW. 03 Rawa Makmur Permai Village, Bengkulu City after iron (Fe) $1.39 \mathrm{mg} / \mathrm{L}$ obtained measurements. From the results of measurements in the initial survey, it was found that the water from the digging well of the residents of RT.04 RW.03 in the Bengkulu City Rawa Makmur Permai Village still exceeded the threshold required by the Indonesian Minister of
\end{abstract}


Health Regulation No. 32 of 2017. The purpose of this study was to determine the decrease in Fe content before and after treatment using variations in the thickness of the combination of coal and coffee shell $20 \mathrm{~cm}, 30 \mathrm{~cm}$, and $50 \mathrm{~cm}$ and to determine the most effective thickness variation to reduce Fe content. This type of research uses the semi-experimental method (Quasi Experimental) with a post test with control group design, namely research conducted before and after treatment. Then look for differences between the measurements of both and this difference is considered as a result of treatment. The results of the study obtained the most effective thickness variations to reduce Fe content with a thickness of $50 \mathrm{~cm}$ which can reduce levels of iron $(\mathrm{Fe})$ to $51.79 \%$.

\section{Keywords: Adsorbents, Coal Waste, Coffee Shell Waste, Iron Content, Dug Wells}

\section{PENDAHULUAN}

Air di permukaan tanah dan laut menguap ke udara. Uap air tersebut bergerak dan naik ke atmosfer, yang kemudian mengalami kondensasi dan berubah menjadi titik-titik air yang berbentuk awan. Selanjutnya titik-titik air tersebut jatuh sebagai hujan ke permukaan laut dan daratan. Hujan yang jatuh sebagian tertahan oleh tumbuh-tumbuhan (intersepsi) dan selebihnya sampai ke permukaan tanah. Air yang meresap ke dalam tanah sebagian mengalir di dalam tanah (perkolasi) mengisi air tanah yang kemudian keluar sebagai mata air atau mengalir ke sungai. Akhirnya aliran air di sungai akan sampai ke laut. Proses tersebut berlangsung terus menerus yang disebut dengan siklus hidrologi (Triatmadja, 2008 dalam Mampuk CR, 2014).

Air tanah alias air sumur merupakan sumber air bersih terbesar yang digunakan. Permasalahan yang timbul yakni sering dijumpai bahwa kualitas air tanah maupun air sungai yang digunakan masyarakat kurang memenuhi syarat sebagai air bersih yang sehat bahkan di beberapa tempat bahkan tidak layak untuk digunakan. Air yang layak digunakan, mempunyai standar persyaratan tertentu yakni persyaratan fisik, kimiawi dan bakteriologis, dan syarat tersebut merupakan satu kesatuan. Jadi jika ada satu saja parameter yang tidak memenuhi syarat maka air tesebut tidak layak untuk digunakan. Pemakaian air bersih yang tidak memenuhi standar kualitas tersebut dapat menimbulkan gangguan kesehatan, baik secara langsung dan cepat maupun tidak langsung dan secara perlahan (Saleh, 2016).

Besi adalah elemen kimiawi yang dapat ditemukan hampir disetiap tempat dibumi pada semua lapisan-lapisan geologis dan badan air. Besi dalam air tanah dapat berbentuk Fe (II) dan Fe(III) terlarut. Fe (II) terlarut dapat tergabung dengan zat organic membentuk suatu senyawa kompleks. Kadar besi maksimum yang diperbolehkan ada di dalam air minum menurut Permenkes Nomor 32 Tahun 2017 sebesar $1 \mathrm{mg} /$ liter (Permenkes RI, 2017).

Air yang terkontaminasi $\mathrm{Fe}$ apabila dikonsumsi terus menerus dimungkinkan terjadi akumulasi logam di dalam tubuh yang menyebabkan keracunan dimana terjadi muntah, kerusakan usus, penuaan dini hingga kematian mendadak, radang sendi, cacat lahir, gusi berdarah, kanker, cardiomyopathies, sirosis ginjal, hepatitis, mudah emosi, hiperaktif, hipertensi, infeksi, insomnia, sakit liver, myasthenia gravis, nausea, mudah gelisah dan iritasi, parkinson, rematik, skizoprenia, sickle-cell anemia, strabismus sampai dengan gangguan penyerapan vitamin dan mineral serta hemokromatis (Kurniawati, 2017).

Batubara merupakan hasil terjemahan dari "coal". Definisi dari batubara itu sendiri menurut Muchjidin (2005). "Batubara adalah batuan sedimen yang secara kimia dan fisika adalah heterogen dan mengandung unsurunsur karbon, hidrogen dan oksigen sebagai unsur utama dan belerang serta nitrogen sebagai unsur tambahan. Zat lain, yaitu senyawa organik pembentuk "ash" tersebar 
sebagai partikel zat mineral dan terpisahpisah di seluruh senyawa batubara. Batubara kotor merupakan hasil dari kegiatan pertambangan batubara, dimana batubara ini merupakan batubara yang mengalami kontaminasi dengan tanah, damar dan beberapa senyawa-senyawa lainnya. Sehingga menyebabkan kualitas kalor dari batubara ini tidak mencapai standar ekspor sehingga batubara kotor ini sangat jarang dimanfaatkan, bahkan sebanyak 600.000 ton batubara kotor ini tidak dimanfaatkan dan terbuang percuma ke dalam sungai (Sukandarrumudi, 2006 dalam Pijer, 2015).

Pusat data dan Sistem Informasi Pertanian (2016) menerangkan bahwa Propinsi Bengkulu merupakan daerah penghasil kopi robusta perkebunan rakyat terbesar ketiga di Indonesia sejak tahun 2012 hingga 2016, produksi kopi robusta di Provinsi Bengkulu pada tahun 2014 tercatat sebesar 54.800 ton. Ketersediaan limbah kulit kopi cukup besar di Propinsi Bengkulu, karena pada pengolahan kopi akan menghasilkan $65 \%$ biji kopi dan $35 \%$ limbah kulit kopi, sedangkan produksi kopi di Propinsi Bengkulu sendiri mencapai 54.800 ton. Limbah kulit kopi mempunyai kandungan serat sebesar 65,2\% (Melyani, 2009).

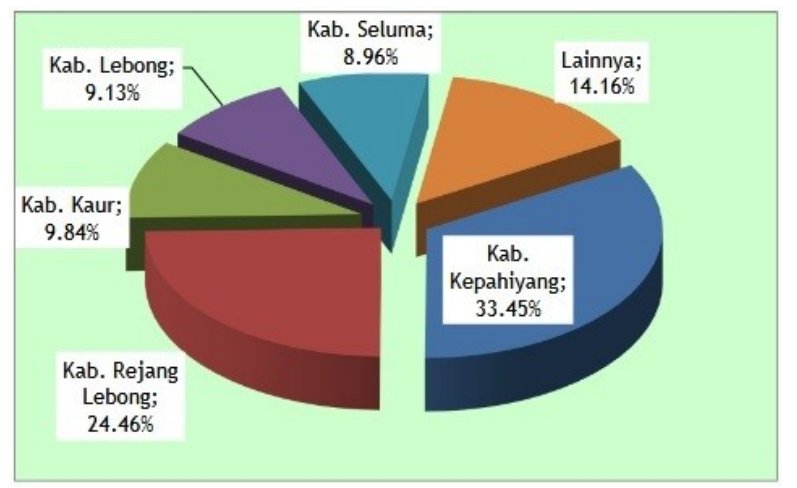

Gambar 1. Sentra Produksi Kopi Robusta Perkebunan Rakyat Di Propinsi Bengkulu Tahun 2014

\section{METODE PENELITIAN}

Jenis penelitian yang akan dilakukan adalah semi eksperimen (quasi experimental), dengan rancangan penelitian post test with control group (Notoadmodjo, 2010)

Tujuan penelitian ini adalah untuk mengetahui penurunan kadar Fe sebelum dan sesudah perlakuan dengan menggunakan variasi ketebalan kombinasi batubara dan cangkang kopi $20 \mathrm{~cm}, 30 \mathrm{~cm}$, dan $50 \mathrm{~cm}$ serta untuk mengetahui variasi ketebalan paling efektif untuk menurunkan kadar Fe.

Lokasi penelitian pada air sumur gali warga Kelurahan Rawa Makmur Permai Kota Bengkulu dan diteliti di bengkel kerja (Workshop) dan Laboratorium Jurusan Kesehatan Lingkungan Poltekkes Kemenkes Bengkulu dengan alokasi waktu penelitian selama 5 bulan.

\section{HASIL PENELITIAN}

Hasil penyaringan dengan media karbon aktif limbah batu bara dan cangkang kopi dalam menurunkan besi (fe) pada sumur gali dengan menggunakan metode SSA (Spektrofotometri Serapan Atom).

Tabel 1 Distribusi Penyerapan kadar Fe pada Kombinasi Limbah Batubara dan Cangkang Kopi

\begin{tabular}{|c|c|c|c|c|c|}
\hline Perlakuan & $\begin{array}{l}\text { Keteba- } \\
\text { lan }\end{array}$ & $\begin{array}{c}\text { N Mea Low } \\
n\end{array}$ & $\mathrm{Up}$ & Min & Max \\
\hline \multirow[t]{8}{*}{$\mathrm{Fe}$} & $50: 50 \mathrm{~cm}$ & $40,6700,529$ & 0,81 & 0,55 & 0,76 \\
\hline & & $0 \quad 5$ & 05 & & \\
\hline & $30: 30 \mathrm{~cm}$ & $40,9050,825$ & 0,98 & 0,85 & 0,97 \\
\hline & & $\begin{array}{ll}0 & 4\end{array}$ & 46 & & \\
\hline & $20: 20 \mathrm{~cm}$ & $41,1151,072$ & 1,15 & 1,09 & 1,15 \\
\hline & & $\begin{array}{ll}0 & 9\end{array}$ & 71 & & \\
\hline & Control & $41,3901,390$ & 1,39 & 1,39 & 1,39 \\
\hline & & $\begin{array}{ll}0 & 0\end{array}$ & 00 & & \\
\hline
\end{tabular}

Berdasarkan tabel 1 rata-rata penurunan $\mathrm{Fe}$ adalah 0,6700 mg/l. Rerata terendah adalah $0,55 \mathrm{mg} / 1$ dan tertinggi 0,76 dengan tingkat kepercayaan $95 \%$ atau signifikansi $5 \%$, rata-rata penurunan pada range 0,5295 $\mathrm{mg} / \mathrm{l}$ sampai dengan $0,8105 \mathrm{mg} / \mathrm{l}$. 


\section{PEMBAHASAN}

Air yang layak digunakan, mempunyai standar persyaratan tertentu yakni persyaratan fisik, kimiawi dan bakteriologis, dan syarat tersebut merupakan satu kesatuan. Jadi jika ada satu saja parameter yang tidak memenuhi syarat maka air tesebut tidak layak untuk digunakan. Pemakaian air bersih yang tidak memenuhi standar kualitas tersebut dapat menimbulkan gangguan kesehatan, baik secara langsung dan cepat maupun tidak langsung dan secara perlahan (Saleh, 2016).

Batubara kotor merupakan hasil dari kegiatan pertambangan batubara, dimana batubara ini merupakan batubara yang mengalami kontaminasi dengan tanah, damar dan beberapa senyawa-senyawa lainnya. Sehingga menyebabkan kualitas kalor dari batubara ini tidak mencapai standar ekspor sehingga batubara kotor ini sangat jarang dimanfaatkan, bahkan sebanyak 600.000 ton batubara kotor ini tidak dimanfaatkan dan terbuang percuma ke dalam sungai. Cangkang kopi adalah kulit buah yang terbentuk karena proses pengelupasan untuk mendapatkan biji kopi tanpa kulit. Jumlah cangkang kopi sebanyak 55\% dari jumlah buah kopi yang dihasilkan, sehingga menyebabkan banyaknya cangkang kopi yang bertumpuk menjadi limbah karena ketidak tahuan masyarakat untuk memanfaatkan nya kembali. Disini peneliti membuat cangkang kopi yang tidak dimanfaatkan menjadi carbon cangkang kopi yang bisa menurunkan kadar besi (fe) pada sumur gali.

Hasil penelitian yang telah dilakukan peneliti pada tanggal 20 November 2018, yang telah diuji di UPT Laboratorium Lingkungan Hidup Kota Bengkulu untuk hasil penyaringan dengan variasi ketebalan karbon aktif kombinasi limbah batu bara dan cangkang kopi $20 \mathrm{~cm}$ didapatkan hasil 1,1150 $\mathrm{mg} / \mathrm{L}$, ketebalan karbon aktif kombinasi limbah batu bara dan cangkang kopi $30 \mathrm{~cm}$ dengan hasil kandungan besi (fe) 0,9050 $\mathrm{mg} / \mathrm{L}$, dan ketebalan karbon aktif kombinasi limbah batu bara dan cangkang kopi $50 \mathrm{~cm}$ yaitu $0,6700 \mathrm{mg} / \mathrm{L}$. Jadi diketahui bahwa karbon aktif kombinasi limbah batu bara dan cangkang kopi dapat menurunkan kadar besi di Rawa Makmur Permai kota Bengkulu dari air yang mengandung Fe sebanyak 51,79 \%.

\section{KESIMPULAN}

Berdasarkan penelitian yang telah dilakukan di Rawa Makmur Permai kota Bengkulu dan pemeriksaan dilakukan di UPT Laboratorium Lingkungan kota Bengkulu dapat disimpulkan :

1. Hasil daya adsorbsi dengan ketebalan karbon aktif cangkang kopi $20 \mathrm{~cm}$ sebesar $1,1150 \mathrm{mg} / \mathrm{L}$ atau $19,78 \%$.

2. Hasil daya adsorbsi dengan ketebalan karbon aktif cangkang kopi $30 \mathrm{~cm}$ sebesar $0,9050 \mathrm{mg} / \mathrm{L}$ atau $34,89 \%$.

3. Hasil daya adsorbsi dengan ketebalan karbon aktif cangkang kopi $50 \mathrm{~cm}$ sebesar $0,6700 \mathrm{mg} / \mathrm{L}$ atau $51,79 \%$.

4. Hasil air sumur gali tanpa perlakuan yaitu $0 \%$.

5. Variasi ketebalan paling efektif untuk menurunkan kadar $\mathrm{Fe}$ dengan ketebalan $50 \mathrm{~cm}$ dapat menurunkan kadar Besi $(\mathrm{Fe})$ hingga $51,79 \%$

\section{SARAN}

1. Penelitian ini dapat digunakan sebagai media pembelajaran mahasiswa khususnya mata kuliah PAPLC

2. Untuk penelitian lebih lanjut dapat Dapat menjadi pertimbangan untuk penelitian sejenis dengan massa waktu dan ketebalan yang berbeda-beda.

\section{DAFTAR PUSTAKA}

Kurniawati dkk, 2017. Pasir Vulkanik sebagai Media Filtrasi dalam Pengolahan Air Bersih Sederhana untuk Menurunkan Kandungan Besi (Fe), Mangan (Mn) dan Kekeruhan Air Sumur Gali. Sanitasi: Jurnal Kesehatan Lingkungan Vol. 9, No.1, Agustus 2017, pp.20-25. Jurusan Kesehatan Lingkungan Poltekkes 
Kemenkes Yogyakarta.

Mampuk CR, 2014. Pengembangan Sistem Penyediaan Air Bersih Di Kecamatan Poso Kota Sulawesi Tengah. Jurnal Sipil Statik Vol.2 No.5, Juli 2014. Universitas Sam Ratulangi Manado

Melyani, V. 2009. Petani Kopi Indonesia Sulit Kalahkan Brasil. URL:http://www. Tempointeraktif. com/hg/bisnis/2009/07/02/brk,20090702184943, id.html.

Muchjidin, 2005. Pengendalian Mutu Dalam Industri Batubara. Penerbit ITB, Bandung.

Permenkes RI Nomor 32 Tahun 2017. Tentang Baku Mutu Kesehatan Lingkungan dan Persyaratan Kesehatan Air Untuk Keperluan Higiene Sanitasi, Kolam Renang, Solus Per Aqua dan Pemandian Umum.

Pijer, 2015. Pemanfaatan Arang Aktif Dari Batubara Kotor (Dirty Coal) Sebagai Adsorben Ion Logam Mn(II) dan Ag(I). Jurnal Pendidikan Kimia Vol.7, No.2, Agustus 2015, 40-48. Universitas Medan.

Pusat Data dan Sistem Informasi Pertanian, 2016. Outlook Kopi Komoditas Pertanian Subsektor Perkebunan. Kementerian Pertanian Jakarta.

Saleh. 2016. Penurunan Kadar Besi (Fe) Pada Air Sumur Gali. Surabaya: Institut Teknologi Surabaya.

Triatmadja R, 2008. Sistem Penyediaan Air Minum Perpipaan, Yogyakarta 